\title{
MLETAČKI LAZARETI BOKE KOTORSKE
}

Ilija LALOŠEVIĆ

Arhitektonski fakultet Univerzitet Crne Gore

Podgorica, Crna Gora
UDK: 614.4:904.72(497 Boka Kotorska)

DOI: http://doi.org/10.21857/mjrl3ux449

Prethodno priopćenje

Prihvaćeno: 6. rujna 2016.

Autor u radu donosi sistematizirana dosadašnja znanja o lazaretima Boke Kotorske, upotpunjena historijskim podatcima i planovima iz mletačkih arhiva te rekognosciranim objektima, odnosno njihovim arheološkim i arhitektonskim ostatcima in situ. U Boki Kotorskoj nastanak lazareta vezan je za prihvaćanje vlasti Mletačke Republike 1420. godine. Najstariji lazaret bio je u samom Kotoru, a karantena se izdržavala i na lokacijama udaljenim od grada, ispred Đurića kod tjesnaca Verige, na otoku Stradioti u blizini Tivta, u Žanjicama kod Herceg-Novog itd. Usavršavanjem zdravstvenih mjera i vezivanjem funkcije lazareta za trgovinu robom nakon raskuživanja i kontrole, postepeno je došlo do približavanja lazareta gradovima i njihovim lukama i tržnicama. Kotorski lazaret nalazio se u neposrednoj blizini luke i gradskih bedema, a novi lazareti grade se u Herceg-Novom nakon njegova oslobođenja od Turaka 1687. godine. Tada nastaje lazaret na Toploj, predgrađu Herceg-Novog, gdje se još mogu rekognoscirati njegovi ostatci uklopljeni u novije građevine, a potom nešto dalje od grada, u Meljinama, koji je ostao autentično sačuvan do naših dana. Nažalost, najnoviji radovi na adaptaciji ovog objekta u velikoj su mjeri narušili njegovu autentičnost, a time i svojstva kulturnog dobra.

Ključne riječi: lazaret, Mletačka Republika, Boka Kotorska, Kotor, Herceg-Novi.

\section{UVOD}

Cilj rada je sistematiziranje dosadašnjih znanja o lazaretima Boke Kotorske i njihovo upotpunjavanje dodatnim povijesnim podatcima i planovima iz mletačkih arhiva, posebno Državnog arhiva Venecije, a potom rekognosciranje relevantnih sačuvanih objekata, odnosno njihovih arheoloških i arhitektonskih ostataka sačuvanih in situ. Naime, nakon propasti Mletačke Republike došlo je do prestanka funkcije ovih objekata, što je rezultiralo promjenom njihove namjene, radikalnim intervencijama na graditeljskoj strukturi, pa i rušenjem u cjelini. Radom se želi skrenuti pažnja na značaj ove specifične kategorije graditeljske baštine kako bi se sačuvali preostali dijelovi arhitektonskih kompleksa i drugi karakteristični povijesni artefakti. Ovo utoliko prije što su neki od lazareta svojevremeno srušeni u cjelini, a u novije vrijeme rekognoscirani su tek njihovi arheološki ostatci (Kotorski lazaret), drugi su sačuvani u jedva prepoznatljivim fragmentima (Lazaret na Toploj) ili im je radikalno izmijenjena autentičnost $u$ suvremenim adaptacijama (Lazaret u Meljinama). 
Opseg rada povijesno je omeđen mletačkom upravom u Boki Kotorskoj od 1420. do pada Republike 1797. godine. Za dio ovog perioda karakteristični su i složeni strateško-prostorni odnosi, gdje je istovremeno s mletačkom upravom u Kotoru i južnom dijelu Boke postojala turska uprava (1482. - 1687. godine) u sjevernom dijelu Boke i gradovima Risnu i Herceg-Novom, osim Perasta i njegovih posjeda. Pored sigurnosnih, strateških i drugih posljedica, ova činjenica imala je značajan utjecaj na zdravstveno-sanitetske prilike u Boki jer se zaraza često širila $s$ turskih na susjedne mletačke teritorije, odakle je zbog jakih trgovačkih veza mogla biti lako prenesena na druge mletačke posjede, pa i samu Veneciju. Situacija se u strateškom smislu izmijenila oslobođenjem prostora od Orahovca i Risna do Kumbora 1684., a potom i zauzećem samog Herceg-Novog 1687. godine. No, sanitetske prilike ostale su i dalje složene intenziviranjem mletačke trgovine u Boki s otomanskim teritorijima u unutrašnjosti Balkana, što je zapravo i rezultiralo izgradnjom novog, suvremenog i prostranog lazareta u Meljinama.

Lazaretima, kao specifičnim objektima za provođenje sanitetskih kontrola i zdravstveno-preventivnih mjera, bavili su se, u sklopu širih povijesnih istraživanja lokalni povjesničari Boke Kotorske: Milivoj Milošević, Maksim Zloković, Slavko Mijušković, Miloš Milošević i drugi. ${ }^{1}$

$\mathrm{U}$ novije vrijeme pojavilo se nekoliko monografskih radova gdje je fragmentarno obuhvaćena i ova problematika, kao jedan od segmenata mletačkog arhitektonsko-građevinskog stvaralaštva. ${ }^{2}$

Namjera ovog rada je sintetizirati povijesne podatke starijih autora i novopronađenih arhivskih podataka, osobito starih planova i projektne dokumentacije, te da se, uz njihovu usporednu analizu s ostacima in situ, donesu novi zaključci i znanja o lazaretima Boke Kotorske mletačkog perioda te da se tako potvrdi pretpostavka o njihovu povijesno-arhitektonskom značaju.

Lazareti $^{3}$ su specifični sanitetski, zdravstveni objekti, karantenske stanice stalnog karaktera, locirani van gradske jezgre na manjoj ili većoj udaljenosti, u lukama ili njihovoj blizini, odnosno na kraju plovnih puteva. Oni su služili

1 Milivoje Š. MilošEvić, Lazareti na Crnogorskom primorju, Godišnjak Pomorskog muzeja u Kotoru, br. 8, Kotor, 1959.; Maksim Zloković, Zdravstvene ustanove u hercegnovskom kraju za vrijeme Mletačke republike, Boka, 13-14, Herceg-Novi, 1982.; Slavko MijušKović, Osnivanje i reorganizovanje jedne srednjovjekovne bokeljske zdravstveno-preventivne institucije, Boka, 5 , Herceg-Novi, 1973.; Miloš MilošEvić, Zdravstvena kultura u Boki Kotorskoj za vrijeme mletačke vladavine (1420-1797), Acta historica Medicinae, Pharmaciae, Veterinae, XIV, br. 2, Beograd, 1974.

2 Darka Bilıć, Inženjeri u službi Mletačke Republike, Književni krug Split, Split, 2013.; Ilija LALOŠEvIĆ, Fortifikacijska arbitektura Boke Kotorske venecijanskog perioda (XV-XVIII vijek), monografska izdanja, Podgorica, 2016.

3 Termin „lazaret“ nastao je od Lazara, biblijskog gubavog prosjaka: M. Š. MıLošEvıć, Lazareti na Crnogorskom primorju, 57. 
za upućivanje i zadržavanje zaraženih ili sumnjivih brodova, njihovih posada, putnika i tereta da se podvrgnu karanteni. ${ }^{4}$ Lazareti su zbog potrebe stroge kontrole uvijek dobro ograđeni, ponekad su se nalazili uz same gradske bedeme (primjer Kotora), a često su bili i u situaciji da provode obrambene aktivnosti. ${ }^{5}$

Lazareti Kotora i Boke Kotorske bili su uz Splitski lazaret, također na teritoriji Venecije, i onaj u Dubrovniku najznačajnije sanitetske institucije na istočnoj jadranskoj obali. U Kotoru se u poznatim povijesnim izvorima karantena prvi put spominje 1431. godine, ubrzo nakon preuzimanja Kotora od strane Mletačke Republike. Po navodima Kovijanića i Stjepčevića, tada je jedan kotorski brod, prilikom povratka iz Molfete, izdržao karantenu ispred Đurića, ${ }^{6}$ naselja u blizini tjesnaca Verige gdje su se obavljale sigurnosne i sanitetske kontrole. $U$ tom periodu strah od zaraze bio je velik, pa su se zdravstvene kontrole i karantena obavljali daleko od grada. Pored Đurića i otok Stradioti, daleko od grada, u blizini Tivta, služio je Kotoranima kao sklonište u doba epidemija. ${ }^{7}$

Početkom XVII. stoljeća na otoku Stradioti (danas Sveti Marko) postojao je lazaret. ${ }^{8}$ Prema S. Mijuškoviću, on je vjerojatno i stariji od kotorskog, s obzirom na ustaljenu praksu XV. - XVI. stoljeća da se lazareti smještaju daleko od grada, na nekom usamljenom otoku, po mogućnosti u blizini manastira. U tom smislu otok Stradioti bio je idealna lokacija za ovu namjenu. Usavršavanjem zdravstvenih mjera i vezivanjem funkcije lazareta za trgovinu robom nakon raskuživanja i kontrole, postepeno je došlo do približavanja lazareta gradovima i njihovim lukama i tržnicama. ${ }^{9}$

\section{KOTORSKI LAZARET}

Zdravstveni ured (Magistrato alla sanita) u Kotoru osnovan je odredbom donesenom u Malom i Tajnom gradskom vijeću 1437. godine. Odredba spada u odluke donijete pod mletačkom vlašću („Partes captae Sub Domin. Venet.“) u vrijeme Pavla Kontarinija, kneza i kapetana Kotora, i njome je određeno

4 Pojam „karantena“ dolazi od tal. quaranta $=40$, odnosno broja dana koliko se u staroj medicini smatralo da je potrebno proći od inkubacije do pojave bolesti, dakle broja dana koliko su putnici i roba zadržavani u izolaciji u lazaretu, M. Š. MilošEvić, Lazareti na Crnogorskom primorju, 57.

5 I. LALOŠEVIĆ, Fortifikacijska arbitektura Boke Kotorske venecijanskog perioda (XV-XVIII vijek), 170 $-176$.

6 Risto Kovijanić, Ivo StjePČEvić, Kulturni život staroga Kotora, II, Cetinje, 1957., 14.

M. ZLOKović, Zdravstvene ustanove u hercegnovskom kraju za vrijeme Mletačke republike, 158.

M. Š. MiLošEvić, Lazareti na Crnogorskom primorju, 59.

9 S. MijušKović, Osnivanje i reorganizovanje jedne srednjovjekovne bokeljske zdravstvenopreventivne institucije, 29. 
da se svakog Đurđevdana biraju po tri općinska provizora iz redova vlastele za očuvanje zdravlja u gradu. Njihov je zadatak bio da provjeravaju zdravstveno stanje svih osoba (domaćih i stranaca) koje dolaze u grad bilo kopnom ili morem i da onima koji stižu iz krajeva zahvaćenim bolestima („de locis morbosis“) ne dozvole ulazak u gradski distrikt, već da ih konfiniraju („per menses, septimanas $\&$ dies“) i naplate im kazne. ${ }^{10}$ Prvi spomen lazareta u Kotoru imamo 1572.godine, u zoni Gurdića („lazzaretto fuori della porta del Gordichio di questa citta di Cattaro"). ${ }^{11}$ Međutim, vrlo vjerojatno je lazaret u Kotoru postojao znatno ranije, ako ne na ovoj lokaciji, tako bliskoj gradu, onda na nekoj u okolici, s obzirom na to da je Venecija poduzimala stroge mjere protiv unošenja zaraze na svoj teritorij i imala svoje stalne lazarete još u prvoj polovini XV. stoljeća.

Drugi lazaret spominje se 1622 . godine, s naznačenom lokacijom „alla Fiumera", ${ }^{12}$ dakle također u neposrednoj blizini kotorskih bedema, na obali Škurde, u dijelu vrta kasnije gradske kavane, na mjestu koje nam je poznato iz kasnijih venecijanskih planova. Lazaretom je rukovodio prior, pod nadzorom Magistrata, od službenika su postojali redovni i vanredni stražari i nosači. ${ }^{13}$

Iz perioda oko 1780. godine imamo zasad jedini poznati plan kotorskog lazareta (Sl. 1.), skicu čiji je autor Pietro Alessandro Ganassa, s naznakama dijelova koje treba restaurirati, prijedlogom podjele dvorišta i formiranja groblja $s$ druge strane rijeke i sl.

Po Montalbotiju, autoru katastika mletačkih javnih građevina iz 1788 . godine, lazaret se sastojao od kvadratnog dvorišta ograđenog kamenim zidom s jednim dobro kontroliranim ulazom („porta fatta a barriera di muro“) na čijoj se sredini nalazio bunar. Objekt postavljen na strani prema rijeci sastojao se od dva dijela različite visine, $u$ prizemlju su bile štale, a na katu, $s$ posebnim vanjskim stubištem, jedna velika prostorija („camerone“) za boravak ljudi. ${ }^{14}$

General Matteo Dixon u svom izvještaju iz druge polovine XVIII. stoljeća ${ }^{15}$ predlaže izgradnju mola i preuređenje lazareta za potrebe galija. Na ovaj način

$10 \quad$ Statuta et Leges Civitatis Cathari, Venettis, 1613., 405 - 407.

11 Crna Gora - Istorijski arhiv Kotor, Kotor (dalje CG-IAK), Upravno-politički spisi vanrednih providura Mletačke republike (dalje: UPM II), knj. 61, 1287 - 1289.

12 M. Š. MiLošEvić, Lazareti na Crnogorskom primorju, 58 (autor ovaj lazaret prezentira kao prvi gradski, kotorski, na lokaciji i u okviru fizičkih struktura sačuvanih do tridesetih godina XX. stoljeća).

13 S. MrJušKović, Osnivanje i reorganizovanje jedne srednjovjekovne bokeljske zdravstvenopreventivne institucije, 29.

14 Gligor Stanojević, Popisi građevina Boke Kotorske iz 1788. g., Spomenik Srpske akademije nauka i umetnosti, CXXVII, Beograd, 1986., 141.

15 Jovan Martinović, Jedan opis utvrđenja Kotora iz 1769. godine, Godišnjak Pomorskog muzeja u Kotoru, XXXVII-XXXVIII, Kotor, 1989.-1990., 17. 
skladišta unutar grada bila bi dovoljna za potrebe garnizona, a eskarpa i bedemi bili bi oslobođeni od svake gradnje. Po njegovu prijedlogu novi lazaret trebalo bi izgraditi negdje na sjeveru rijeke jer je trenutna lokacija preblizu tvrđavi i pristaništu gdje je velika koncentracija korisnika.

Nakon gradnje lazareta u Meljinama Kotorski lazaret drastično je izgubio na značaju jer su sve sanitarne kontrole vezane za pomorsku trgovinu morale biti obavljene u Herceg-Novom, na ulazu u zaljev, gdje se roba najčešće odmah i prodavala. Kotorani su zbog toga protestirali, ali bezuspješno, tako da je lazaret još jedno vrijeme djelovao, oslanjajući se na gotovo beznačajan promet robe koja je dolazila iz unutrašnjosti kopnenim putem. Po ukidanju lazareta, padom mletačke vlasti, njegove zgrade i dvorišta austrijska vojska upotrijebila je za građevinsko gazdinstvo (Bauhof), koje se prostiralo u dijelu današnjeg parka uz rijeku (Sl. 2.), čiji su objekti srušeni između dva svjetska rata prilikom izgradnje današnje zgrade Lučke kapetanije.

Tijekom radova na uređenju kotorske rive 2008. godine pronađeni su ostatci temeljnih zidova lazareta i u njima ugrađene velike kamene ploče s grbovima kotorskih providura postavljene horizontalno. ${ }^{16}$ Spolije su bile ugrađene na samom dnu temeljnih zidova pa se pretpostavlja da je to urađeno radi boljeg prenošenja opterećenja zidova na relativno loš muljevit i nasut teren.

\section{LAZARET NA TOPLOJ}

Oduzevši Herceg-Novi iz osmanskih ruku 1687. godine, Mlečani u njemu, koliko je poznato, nisu zatekli nikakvu organiziranu zdravstvenu službu ni lazaret, ${ }^{17}$ iako je grad obavljao vrlo živu trgovinu sa zaleđem. U gradu je u skladu s načinom života i funkcioniranjem Osmanskog Carstva postojao han, koji se po Evliji Čelebiji nalazio u blizini male džamije Sulejman-age Ramovića, nedaleko od glavnih gradskih vrata (danas Sat-kule). Han je bio okružen otvorenim dvorištem i okolnim zgradama u kojima su bila skladišta i konačišta za putnike i kočijaše. ${ }^{18}$ Imajući u vidu stratešku i urbanističku dispoziciju u okviru Boke Kotorske, stroge mletačke sanitarne propise, kao i činjenicu da je u grad svakodnevno

16 Konzervatorski nadzor nad radovima vodio je autor ovog rada, a za arheološko praćenje je bila zadužena kolegica Vilma Kovačević.

17 S. Mijušković, Osnivanje i reorganizovanje jedne srednjovjekovne bokeljske zdravstvenopreventivne institucije, 5 .

18 Petar SAger, Komentar i dopuna opisu Herceg-Novoga i Boke po Evliji Čelebiji 1664. godine, Boka, 4, Herceg-Novi, 1972., 220. 
stizala razna trgovačka roba iz susjedne Hercegovine, ubrzo nakon oslobađanja Herceg-Novog od Turaka odlučeno je da se pristupi gradnji lazareta.

Stari hercegnovski lazaret bio je sagrađen u samom gradu, ispod manastira sv. Antona, jugozapadno od kule Burovića, na putu prema Toploj (i danas se taj lokalitet u Herceg-Novom zove Lazaret), nakon potpisivanja Karlovačkog mira (1699.), kojim su Mlečani potvrdili granice osvojenih područja, odnosno legalizirali vlast nad osvojenim teritorijama. $\mathrm{O}$ tome govori jedan dokument Kotorskog arhiva („Stabiliti appena i confini, vi fu aperto un lazzaretto“) ${ }^{19}$ koji potvrđuje dataciju Toma Popovića (1700. godina). ${ }^{20}$

Lazaret na Toploj nije bio dugo u funkciji jer je, prema podatcima koje navodi $\mathrm{T}$. Popović, doživio oštećenja uslijed klizišta. ${ }^{21}$ Međutim, izgleda da ovaj lazaret, čiji se ostatci još i danas vide i koji ukazuju da se građevina mogla konsolidirati, nije prestao postojati na tom mjestu iz razloga koje navodi Popović. Izgleda da je klizište, na kojem je gotovo čitav Herceg-Novi, bilo povodom, a da je pravi razlog za podizanje novog lazareta bio nepogodan položaj na kome je bio podignut stari. Naime, na ovom dijelu obale nije bio moguć pristup brodova ni pri najmanjem nevremenu, a još manje njihovo zadržavanje radi iskrcavanja tereta i izdržavanja karantene.

Ubrzo nakon osnivanja lazareta na Toploj, dekretom nadprovidura („sopraproveditore“) i providura zaduženog za zdravstvo („proveditore alla sanita“) od 19. svibnja 1701. godine hercegnovskom lazaretu dana je prednost $u$ odnosu na kotorski, na način da je zabranjeno izdržavanje kontumacije brodova u bilo kojem mjestu Dalmacije i Boke izuzev u lazaretima Splita i Herceg-Novog. ${ }^{22}$ Kako je ova odluka teško ekonomski pogodila Kotor, gradsko Veliko vijeće uputilo je prigovor Veneciji, pozivajući se na stare privilegije. Prigovor je odbijen, ali su mletačke vlasti iz njegovih argumenata izvukle pouku o pogrešnoj lokaciji starog lazareta na Toploj i odlučile da na mjestu pogodnijem za pristajanje i zadržavanje brodova, $u$ Meljinama, pristupe izgradnji novog lazareta. ${ }^{23}$

Jedan plan iz Venecijanskog arhiva (Sl.3. $)^{24}$ potvrđuje nam da se istovremeno $s$ razmatranjem ideje o gradnji novog lazareta u početku razmišljalo i o varijanti obnove i dogradnje starog. Ovo je ujedno i jedini poznati plan lazareta na Toploj (u gornjem dijelu crteža), koji pokazuje dispoziciju objekata i funkciju u okviru

19 CG-IAK, UPM II, knj. 74, 525.

20 Tomo K. Popović, Herceg-Novi, istorijske bilješke, knjiga prva, Dubrovnik, 1924., 99.

21 T. K. Popović, Herceg-Novi, 99.

22 CG-IAK, Sudsko-notarske knjige (dalje: SN), knj. 128, 1023.

23 S. Mijušković, Osnivanje i reorganizovanje jedne srednjovjekovne bokeljske zdravstvenopreventivne institucije, 9 .

24 I. LALOŠEVIĆ, Fortifikacijska arhitektura Boke Kotorske venecijanskog perioda (XV-XVIII vijek), 285, prilog 104, plan se nalazi u ASV pod signaturom Sanita b. 417. 
kompleksa i potvrđuje da je imao i obrambena svojstva i elemente, četiri kule na uglovima (označene u legendi kao Y. Torrette per li Guardiani).

Iz Montalbotijeva katastika saznajemo da je građevina, iako napuštena i $\mathrm{u}$ lošem stanju, bila u to vrijeme još u funkciji (1788. godine). ${ }^{25}$ Zauzimala je kvadratni prostor stranice 22 sežnja (oko $40 \mathrm{~m}$ ), ograđen zidom visine 1 sežanj i 3 stope (oko $3 \mathrm{~m}$ ). Mnogi zidovi u unutrašnjosti bili su skloni padu („muracche cadenti“). Građevinu je održavalo 11 obitelji koje su u njoj stanovale. U okviru lazareta nalazila se mala kuća na dva kata koja je služila za sanitarnu stražu ("guardia di Sanita“).

Kompleks lazareta na Toploj danas nije sačuvan, osim manjih ostataka njegovih ogradnih zidova i stambenih građevina (Sl. 4.) koje su preostale nakon intenzivne nove gradnje na ovoj lokaciji.

\section{LAZARET U MELJINAMA}

Stari lazaret na Toploj, pored problema s pristajanjem i zadržavanjem brodova, nije se uklapao u mletačku koncepciju da od Herceg-Novoga na ulazu u Bokokotorski zaljev stvori veći trgovački centar kao konkurenciju Dubrovniku, pa je slično Splitu ${ }^{26}$ trebalo podići reprezentativni lazaret za pomorsku i karavansku trgovinu ovog dijela istočne jadranske obale. Nova lokacija nađena je u Meljinama, gdje je između 1728. i 1732. godine izgrađena prostrana i impozantna građevina (Sl. 5., Sl. 6.). Tako je eliminiran jedan od uvjerljivih argumenata Kotorana o nepogodnosti hercegnovskog lazareta s navigacijske osnove, iako je Venecija i inače bila odlučila žrtvovati ranije privilegije i tradicije Kotora u ovom pogledu. ${ }^{27}$

Prije početka zidanja novog lazareta izvršeni su obimni pripremni radovi i uređenje terena, nabave materijala i dovođenje vode sa Savine posebno napravljenim kanalom. Voda je dovedena na gradilište u sklopu pripremnih radova, ${ }^{28}$ a ne 1741. godine, kako tvrde Tomo Popović i Milivoj Milošević, na osnovu natpisa na jednoj česmi u lazaretu. ${ }^{29}$ Česma na kojoj stoji natpis

25 G. Stanojević, Popisi građevina Boke Kotorske, 152 - 153.

26 D. Bilı́, Inženjeri u službi Mletačke Republike, 83.

27 M. MilošEvić, Zdravstvena kultura u Boki Kotorskoj za vrijeme mletačke vladavine (1420-1797), 34.

28 CG-IAK UP, knj. 51, $470-473$.

29 T. K. Popović, Herceg-Novi, 99; M. Š. MilošEvić, Lazareti na Crnogorskom primorju, 62. Natpis uklesan na česmi glasi (po Miloševiću): MERCATORUM COMMODO / MARCUS QUIRINI PROV. EXTR. / SEN. CONS. / POSUIT / MDCCXLI; Isti natpis donosi i M. ZLOKović, Zdravstvene ustanove u hercegnovskom kraju, 163. 
postavljena je nakon završetka radova, a moguće da je prije nje postojala starija jednostavnije izrade.

Vodovod lazareta Nakićenović zove „Manastirskom vodom“, koju su redovnici obližnjeg manastira Savine našli i doveli do svoje „mlinice“, a mletačke vlasti skrenule je do lazareta. ${ }^{30}$ Prema Zlokoviću, prilikom gradnje lazareta mletačke su vlasti također odnijele sav isklesan kamen koji je bio pripremljen za gradnju velike manastirske crkve u baroknom stilu, o čemu svjedoči žalba redovnika iz 1732. godine. ${ }^{31}$

U Hercegnovskom arhivu postoji nekoliko dokumenata koji govore o gradnji novog lazareta. Dokument od 30. srpnja 1731. godine predstavlja kopiju pisma od 30. lipnja iste godine, pisanog na Rosama, kojim Luštička općina potražuje od providura Herceg-Novog novac za isporuku vapna za lazaret, koji nije isplaćen zbog problema $s$ javnim financijama („Pub.co danaro“) ${ }^{32}$. Drugi dokument datiran iste godine odnosi se na plaćanje 530 lira općini Krtoli za isporuku vapna i 25 miljara („migliara“) crijepa („copi“) za isto gradilište. ${ }^{33}$ Pored ovih računa nalazi se i potvrda Petra Vukovog Ivoševića iz Krtola od 20. siječnja 1731. godine, da je od providura Pietra Magna primio 120 lira za isporuku vapna za lazaret. ${ }^{34}$

Meljinski lazaret vrlo je kvalitetno koncipiran i sagrađen kompleks, realiziran u najboljoj maniri mletačkog graditeljstva svoga vremena. Lociran je u uvali na početku Meljina od strane manastira Savine. Ispred njega donedavno su se nalazila dva pristaništa, jedno veće s lukobranom i drugo manje ispred same zgrade, u značajnoj mjeri porušena u najnovijim radovima.

Iz spomenutog idejnog projekta (Sl. 3.) vidi se da je lazaret bio zamišljen kao reprezentativna građevina, čije je pročelje trebalo imati stilske karakteristike barokne epohe, $s$ arkadama u prizemlju središnjeg dijela i monumentalnim vanjskim stubištem $s$ obje strane, do prostorija na katu u kojim je bilo sjedište priora. Međutim, u realizaciji projekta, pored drugih manjih odstupanja, odustalo se od reprezentativne fasade centralnog dijela, a stubište je izgrađeno $u$ dvorištu, vjerojatno iz sigurnosnih razloga, kao i druga stubišta i ulazi.

Kompleks lazareta (Sl. 5. - 7.) sa svih je strana okružen visokim kamenim ogradnim zidom. Izvorno je imao samo jedan ulaz kontroliran s morske strane, a drugi bočni, pomoćni, otvoren je tijekom radova na obnovi 1767 . godine i do

\footnotetext{
30 Savo NA KićEnović, Boka, antropogeografska studija, Beograd, 1913., 500.

31 M. Zloković, Zdravstvene ustanove u hercegnovskom kraju, 163.

32 Crna Gora - Arhiv Herceg-Novog (dalje: CG-AHN), Političko-upravni mletački arhiv (dalje: PUMA) fascikla br. 105, 25.

33 CG-AHN, PUMA, 43.

34 CG-AHN, PUMA, 31.
} 
njega se dolazilo mostom preko kanala ispunjenog vodom. $S$ kopnene strane na uglovima su dvije stražarske kule. Iz glavnog dvorišta s česmom na sredini komuniciralo se $s$ bočnim, gdje su s jedne strane bili zaraženi, a s druge sumnjivi putnici i roba. U centralnom dvorištu, u blizini česme, je kapela posvećena sv. Roku, a na suprotnoj strani od glavnog ulaza nalazio se veliki bazen $s$ vodom koji je služio za potapanje i čišćenje zaražene odnosno sumnjive robe.

Planovi lazareta dani u prilogu (Sl. 6., Sl. 7.) urađeni su 1767. godine kao snimak postojećeg stanja s prijedlozima za restauraciju. Naime, prior lazareta Konstantin u svom pismu izvanrednom providuru, kolovoza 1766. godine navodi da je neophodan generalni popravak lazareta. Generalni providur iz Zadra na vijest izvanrednog providura o potrebi popravka lazareta traži da se točno utvrdi stanje lazareta, vrijeme potrebno za popravak, kao i visina troškova. ${ }^{35}$

$\mathrm{Da}$ bi se utvrdio točan stupanj oštećenja angažiran je inženjer Antonio Moser, ${ }^{36}$ koji podnosi izvještaj izvanrednom providuru u Kotoru. Iz tog izvještaja vidi se da priorove tvrdnje o stanju lazareta („ridotto quasi in rovina“) nisu bile pretjerane. Na lazaretu su oštećeni krovovi i tavanice, kapci na prozorima, podovi, ognjišta i dr. Po sugestiji priora, inženjer predlaže da se na bočnoj strani lazareta otvore još jedna, već spomenuta vrata koja bi služila samo za ulazak robe i osoba koje izdržavaju karantenu, da bi se izbjeglo miješanje s osobljem lazareta. ${ }^{37}$ No, o stanju lazareta i poduzetim radovima na njegovoj obnovi ipak najbolje svjedoče detaljni crteži koje je po nalogu generalnog providura tom prilikom izradio inž. Polo Artico. Detaljan opis lazareta s dimenzijama i namjenom prostorija donosi Montalbotijev katastik. On navodi da se pored lazareta nalazi manja katnica u čijem je prizemlju velika peć, a na katu soba i kuhinja koje su koristili turski emini. ${ }^{38}$

Meljinski lazaret jedan je od najbolje očuvanih objekata mletačke arhitekture u Boki Kotorskoj. U Državnom arhivu u Veneciji za njega također postoji izuzetno bogata dokumentacija o gradnji, desetak projekata, crteži izvedenog stanja i adaptacija, kao i brojni troškovnici, predmjeri, predračuni i sl. ${ }^{39}$ Ova dokumentacija od izuzetnog je značaja za proučavanje materijala i tehnika gradnje ne samo ovog objekta već i cijelog perioda i bila bi od velike pomoći u postupku obnove i zaštite objekata mletačkog graditeljskog opusa.

35 CG-IAK, UP, knj. 96, 148, 972, 441.

36 Detaljnije vidi D. Bılıć, Inženjeri u službi Mletačke republike, 226, 229.

37 CG-IAK, UP, knj. 96, 151; Vesna VičEvić, Aktivnosti Hercegnovskog lazareta i zdravstvenog kolegija 1766. godine, Boka,13-14, Herceg-Novi, 1982., 176.

38 G. Stanojević, Popisi građevina Boke Kotorske, 153.

39 IT-ASV, Deputati ed aggiunti sopra il denaro pubblico, b. 845 . 
Ovdje ćemo iznijeti samo najosnovnije karakteristike graditeljskih tehnika i materijala primijenjenih na objektu. Kako je već rečeno, lazaret je građen od lokalnog kamena vapnenca, dijelom već ranije pripremljenog za gradnju velike crkve obližnjeg manastira Savine. Promatrajući zidna platna objekata lazareta, može se zaključiti da su Mlečani sekundarno ugrađivali građevinski kamen i gotove kamene elemente i s nekih starijih srušenih objekata. Poznato je da je prilikom osvajanja Herceg-Novog bilo dosta objekata srušenih u ratnim operacijama koji se više nisu obnavljali, već služili praktično kao „majdan“ kamena već spremnog za gradnju.

Vapno i crijep nabavljani su u Krtolima, koji su tradicionalno vjekovima „goreli klačinu“ i pekli opekarske proizvode, u prvom redu crijep kanalicu, a o ovome za objekt lazareta imamo i neposredne arhivske podatke. Za gradnju je korišten lokalni morski pijesak, nakon tretmana ispiranja slatkom vodom. Kada je u pitanju drvena građa, bilo jelovina („albeo“) ili ariš („larese“), vrlo kvalitetna vrsta borovine, ona je dovožena brodovima iz Venecije jer je u ovim krajevima nije bilo. Građa je stizala na gradilište već spremna za ugradnju, po specifikaciji. Samo jednom prilikom, za restauraciju lazareta 1767. godine (Sl. 6., legenda), naručena je veća količina raznovrsne građe, počevši od greda velikog presjeka („bordonali“) za primarne nosače, preko većih („morali“) i manjih gredica („mezzi morali“), do talpi („ponti“) i dasaka („tavole“), od kojih su neke bile izuzetno velike širine („sfiladone“).40

Budući dajelazaretgrađen praktično na samoj obali, posebna pažnja posvećena je izradi temelja. Pored uobičajene tehnike gradnje temelja u kvalitetnom malteru od crvenice („terra rossa“), ovdje su, sudeći po sačuvanim planovima, primjenjivani i šipovi. Za ovu svrhu obično se koristila hrastovina ili bukovina, koja se mogla nabaviti i u okolnim Krivošijskim planinama. Iz primjera drugih građevina znamo da je bilo slučajeva primjene drvenih greda unutar zidne mase, tzv. santrača, koje su obično imale dva zadatka, da osiguraju zid do očvršćivanja maltera i da prime zatežuće napone, posebno za vrijeme potresa.

$\mathrm{Na}$ lazaretu su izuzetno kvalitetno rađeni lukovi i svodovi, kao i krovne konstrukcije. Iznad arhitravnih otvora izvedeni su rasteretni plitki lukovi, koji premošćuju arhitrav, da ne bi došlo do njegova pucanja uslijed eventualnog slijeganja i seizmičkih pomicanja.

Najbolja potvrda kvalitete ove građevine je njezino korištenje do današnjih dana. Nakon pada Mletačke Republike lazaret je nastavio svoje djelovanje po ustaljenoj praksi, koju je kasnije austrijska uprava prilagođavala svojim

40 Ennio CONCINA, Pietre parole storia, glossario della costruzione nelle fonti veneziane (secoli XVXVIII), Marsilio Editori, Venezia, 1988., 136 („sfiladona“ je termin za dasku širine obično $10-18$ unči, tj. 28,9 do $52,02 \mathrm{~cm}$ ). 
zakonima. Lazaret je bio privremeno zatvoren između 1830. i 1837. godine, da bi definitivno bio ukinut tek 1934. godine. ${ }^{41} \mathrm{Od}$ tada su ga koristile vojne vlasti, sve donedavno. U potresu 1979. godine nije pokazao značajnija oštećenja, što je prava rijetkost s obzirom na njegovu starost, veličinu, lokaciju u blizini morske obale i velika oštećenja okolnih objekata.

Nedavno se pristupilo revitalizaciji ovog izuzetnog kompleksa. U startu pokazan negativan odnos prema graditeljskoj baštini kroz pripremne radove i rušenja na obali i pristaništu, kroz proces adaptacije u potpunosti su uništeni ili uklonjeni gotovo svi autentični elementi: skinute su i odnesene grede drvene međukatne i krovne konstrukcije, izrađene pretežno od kvalitetne borovine ariša, skinut je stari crijep kanalica - „kupa“, obijene su izvorne fuge od vapnenog maltera i zamijenjene novim cementnim, demontirani su pločnici od đuričkog kamena itd. Na ovaj je način integralno i autentično sačuvano kulturno dobro po ukusu i potrebama investitora pretvoreno u svojevrsnu ljušturu, gotovo kulisu. Pri tom nije iskorištena čak ni šansa da se kulturno dobro adekvatno istraži i prouči te da se nalazi in situ usporede s podatcima iz bogate povijesne dokumentacije.

\section{ZAKLJUČAK}

Radom su sistematizirana dosadašnja znanja o lazaretima Boke Kotorske, upotpunjena novopronađenim povijesnim podatcima, posebno projektima i planovima Državnog arhiva Venecije. Podatci su analizirani i uspoređeni sa sačuvanim objektima, odnosno njihovim arheološkim i arhitektonskim ostatcima. Budući da je propašću Mletačke Republike došlo do prestanka funkcije lazareta te promjene njihove namjene, pa i djelomičnog ili rušenja u cjelini, radom je skrenuta pažnja na značaj ove specifične kategorije graditeljske baštine, kako bi se sačuvale preostale građevine i njihovi dijelovi.

Pored podataka o povijesti i arhitektonskoj namjeni ovi objekti svjedoče i o složenim strateško-teritorijalnim odnosima te zdravstvenim, sanitetskim i drugim prilikama u Boki i susjednim područjima.

Sintetiziranjem povijesnih arhivskih podataka, osobito autentične projektne dokumentacije, koju je autor proučio u Državnom arhivu Venecije, te njezinom usporednom analizom s ostatcima in situ, donesena su nova znanja o lazaretima Boke Kotorske mletačkog perioda i potvrđena pretpostavka o njihovu povijesnoarhitektonskom značaju, ne samo na lokalnom već i regionalnom nivou.

41 S. Mijušković, Osnivanje i reorganizovanje jedne srednjovjekovne bokeljske zdravstvenopreventivne institucije, 14 . 


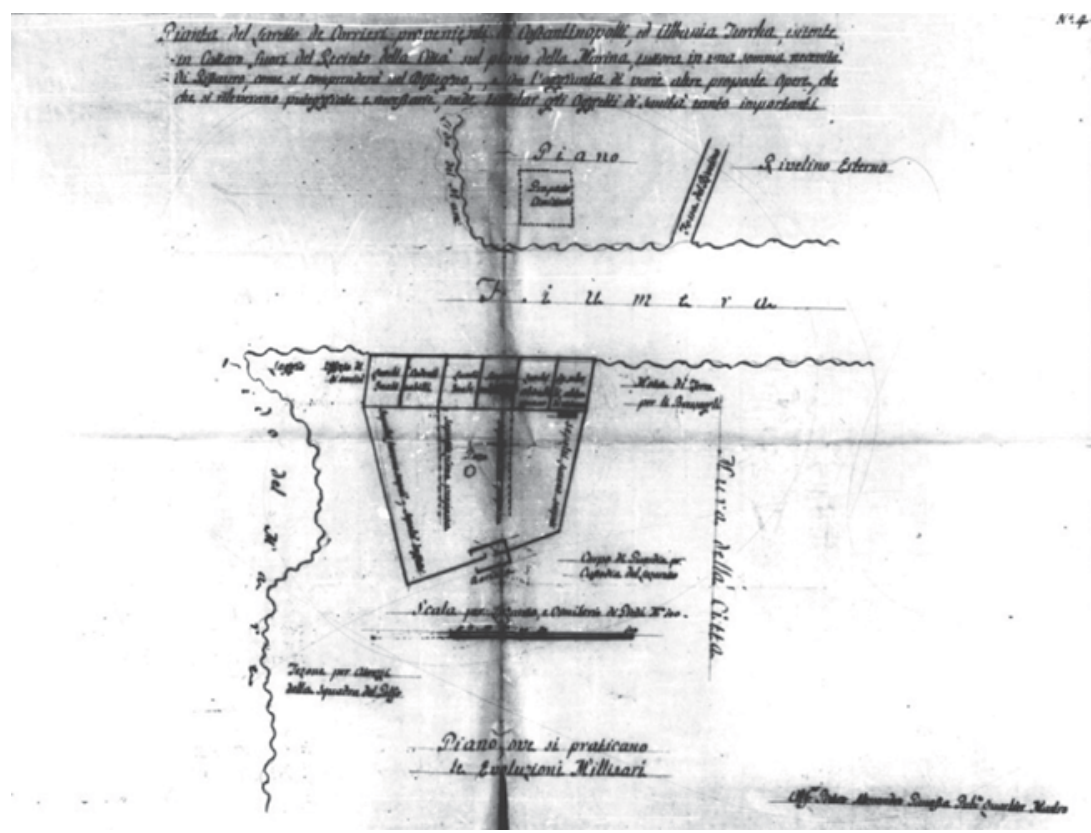

SLIKa 1. Plan Lazareta u Kotoru, a. Pietro Alessandro Ganassa, XVIII st., oko 1781., (IT-ASV, Sanita b. 417.)

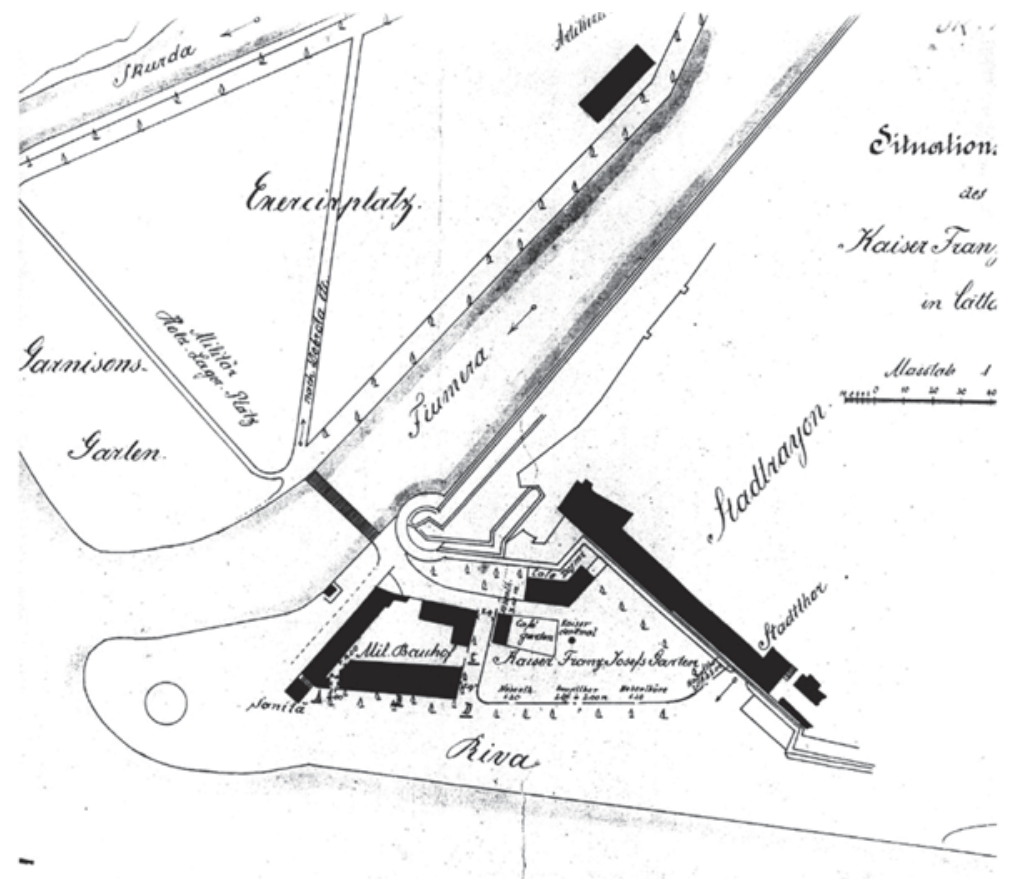

SLIKA 2. Bivši lazaret u Kotoru (dolje lijevo), 1889. (CG-IAK, Opština Kotor /O.K./, CVII - 269) 

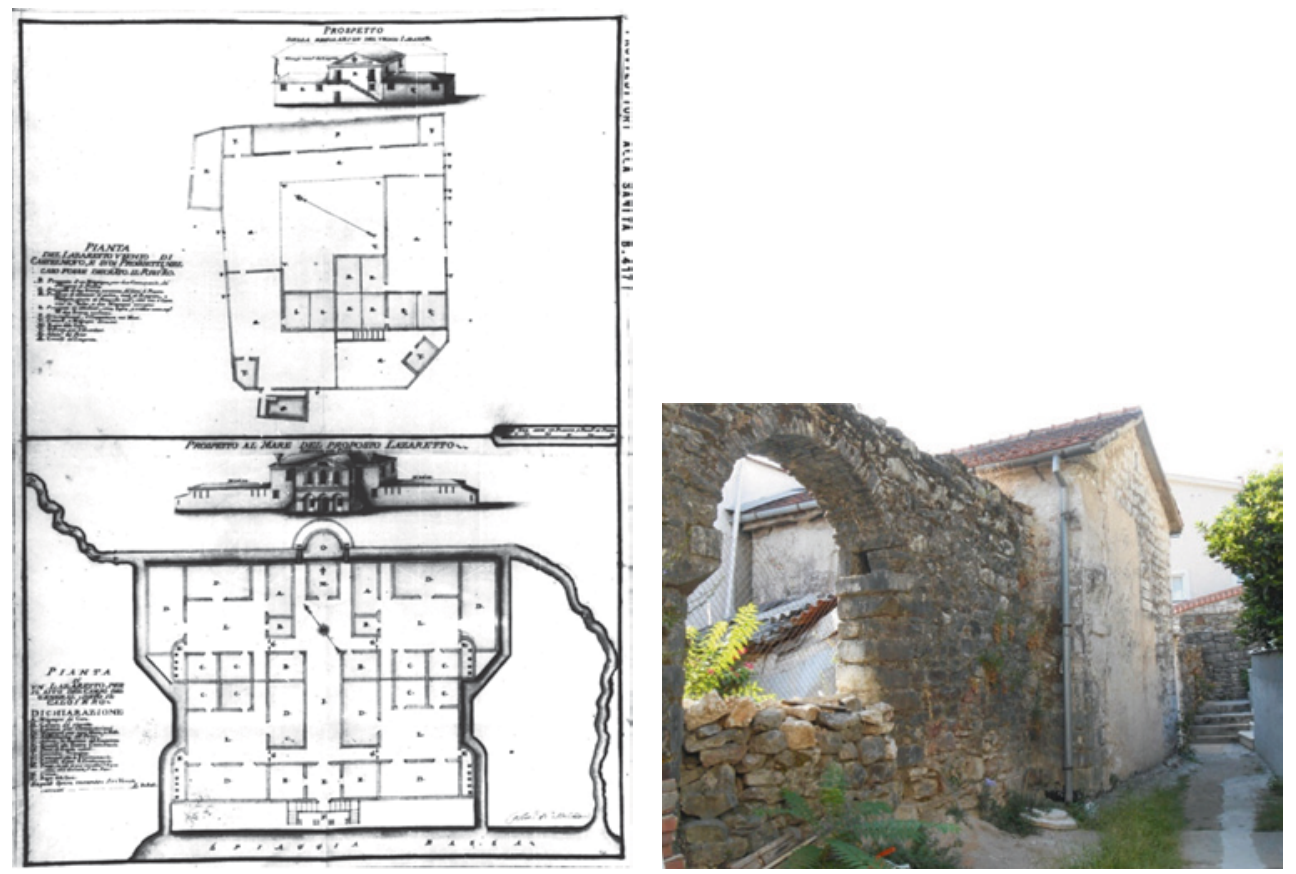

SLIKA 3. Plan Starog lazareta na Toploj i SLIKA 4. Ostatci Starog lazareta na Toploj, prijedlog Novog lazareta u Meljinama, a. Herceg-Novi Francesco Melchiori, oko 1728. g. (IT-ASV, Sanita b. 417)

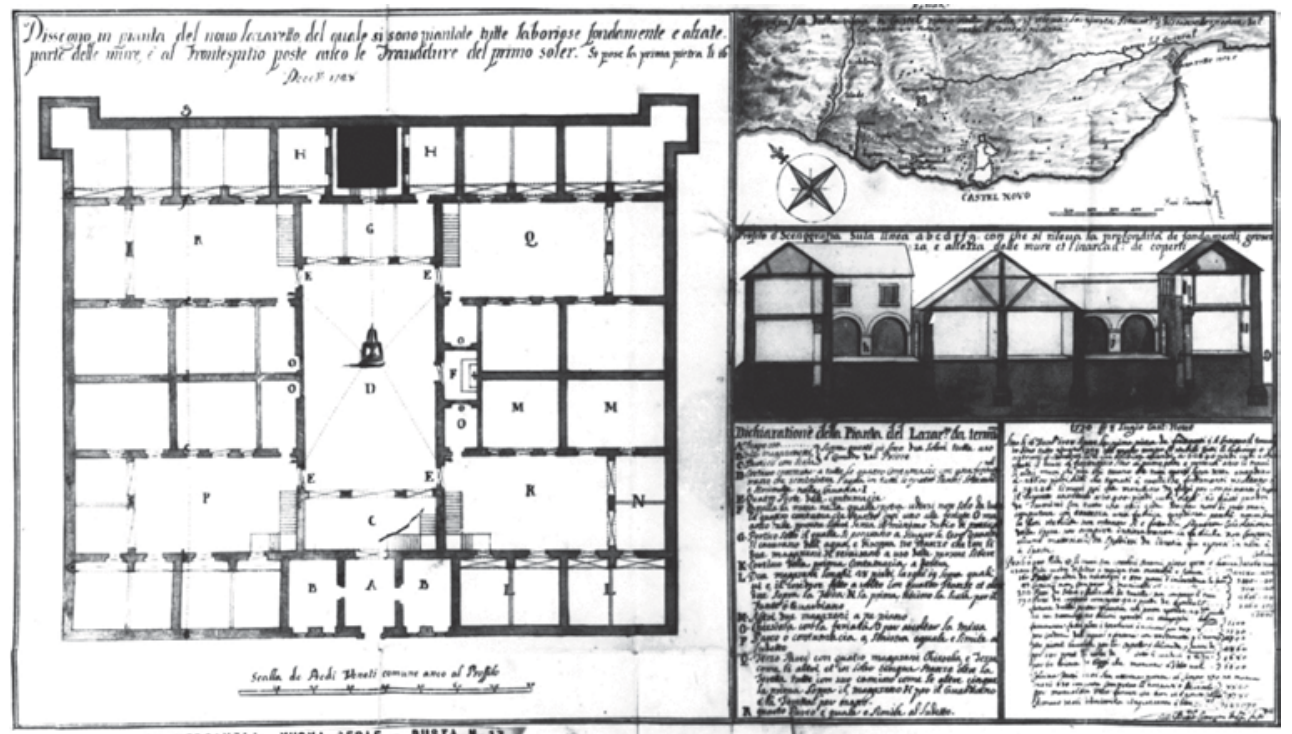

SLIKA 5. Plan Novog lazareta u Meljinama, a. Giovanni Battista Camozini, 1730. g. (IT-ASV, 5 Savii alla mercanzia, b. 17) 


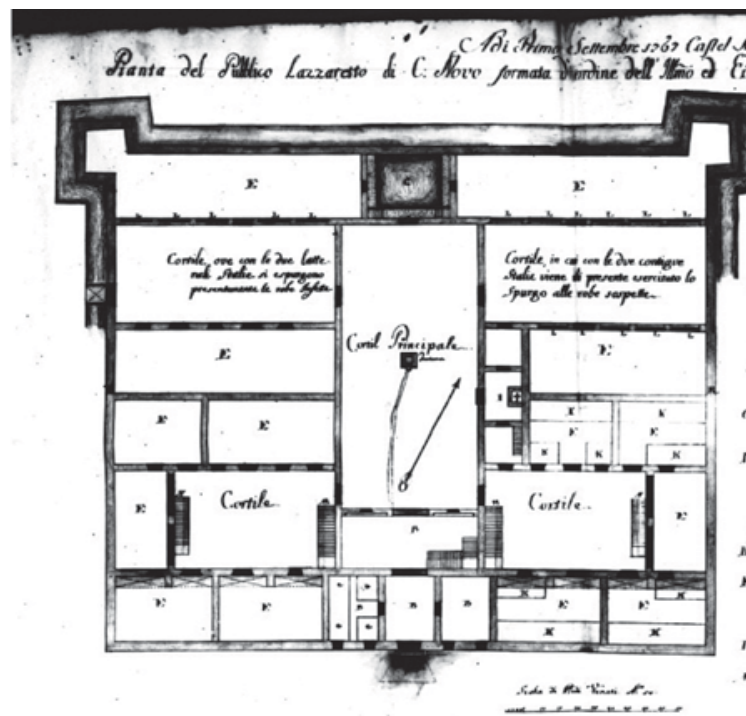

क्र:

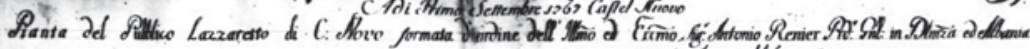

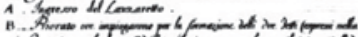

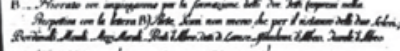

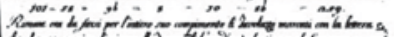

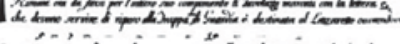

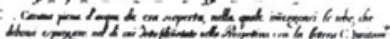

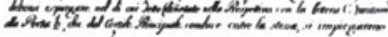

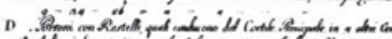

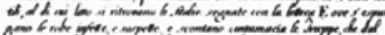

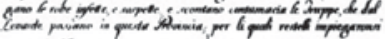

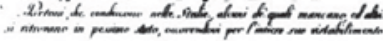

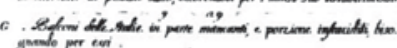

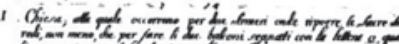

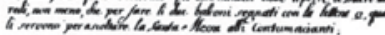

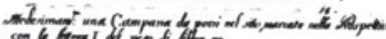

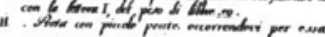

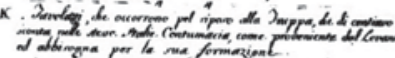

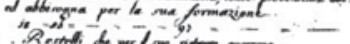

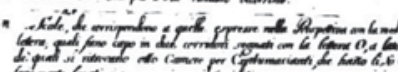

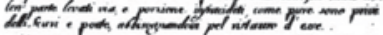
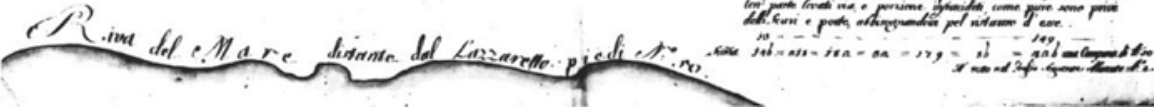

SLIKA 6. Plan adaptacije lazareta u Meljinama, 1767.g. (IT-ASV, Sanita, dis. B. 9 / n 7-2)

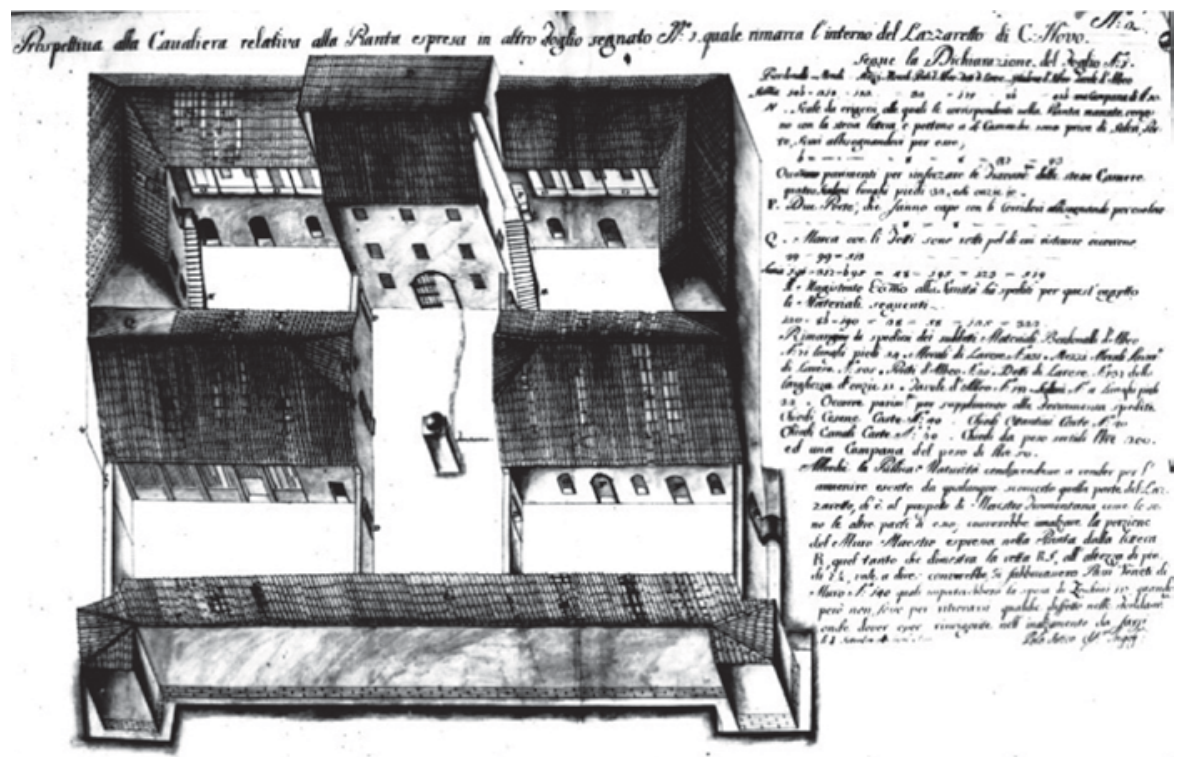

SLIKA 7. Aksonometrija lazareta u Meljinama, 1767. g. (IT-ASV, Sanita, dis. B. 9 / n 7-1) 


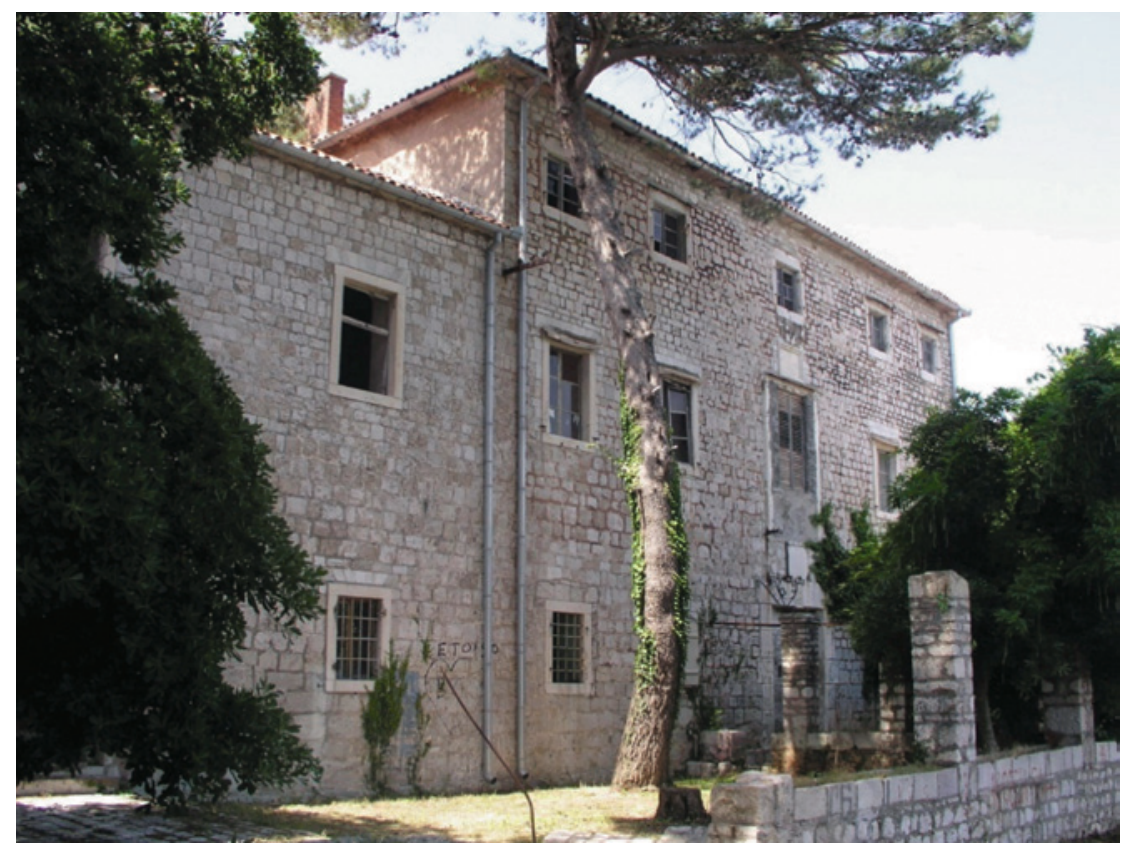

SLIKA 8. Novi mletački lazaret u Meljinama, Herceg-Novi, glavna fasada, prije radova

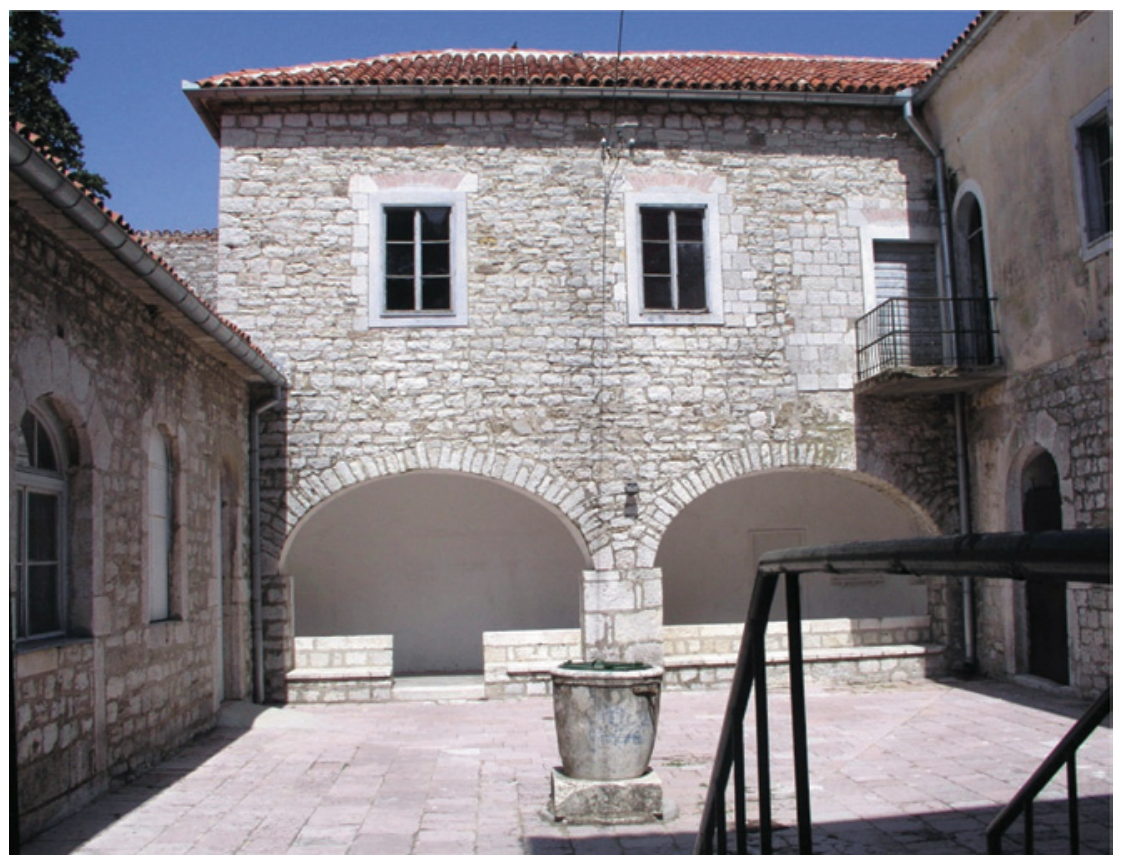

SLIKA 9. Novi mletački lazaret u Meljinama, Herceg-Novi, jedno od unutrašnjih dvorišta, prije radova 


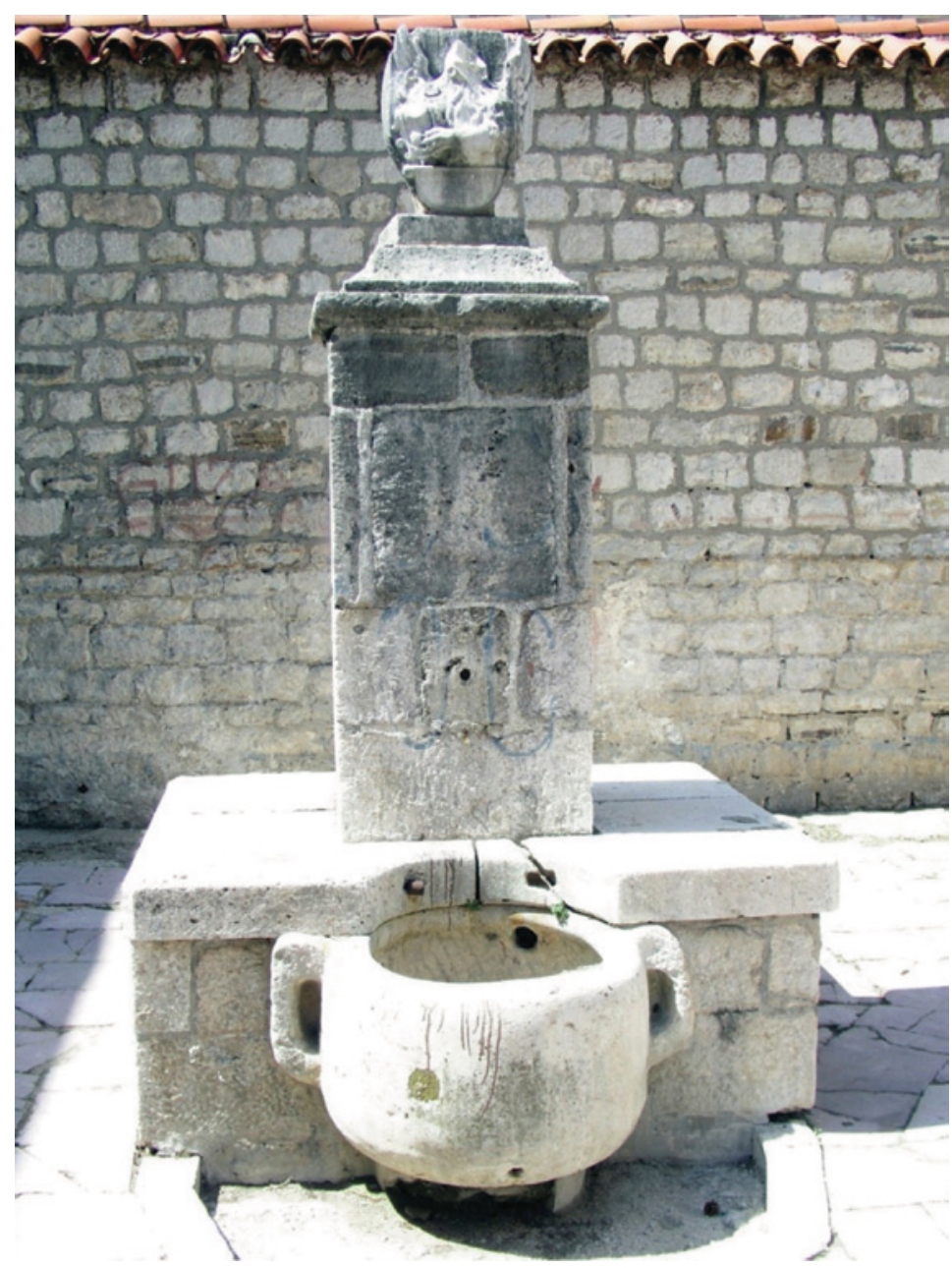

SLIKA 10. Novi mletački lazaret u Meljinama, Herceg-Novi, detalj česme u dvorištu, prije radova 
Ilija LALOŠEVIĆ

VENETIAN LAZARETTOS IN BOKA KOTORSKA

\section{SUMMARY}

Lazarettos are a specific type of hospitals located outside the town centre - closer to or further from it; in ports or in their vicinity; or at the end of waterways. They used to serve for directing and halting infected or suspicious ships, their crews, passengers and cargo, and to put them under quarantine. In Boka Kotorska, the emergence of lazarettos was connected with the acceptance of the authority of Venetian Republic in 1420. In Kotor, quarantine was first mentioned in 1431, when a ship from Kotor survived the quarantine in front of Đurić, far from the town itself. The island of Stradioti near Tivat, which had earlier offered shelter to inhabitants of Kotor during epidemics, served the same purpose at the beginning of the $17^{\text {th }}$ century.

Thanks to improving health measures and linking the function of lazarettos to trading in goods after conducting disinfections and control, the lazarettos gradually grew closer to towns, their ports and markets. The Kotor lazaretto was located very close to the port and the town walls. This was considered unfavourable according to Venetian sources dating from the end of the $17^{\text {th }}$ and the beginning of the $18^{\text {th }}$ century, and hence emphasised as argument in favour of closing the lazaretto in Kotor and opening one in Herceg-Novi instead, after its liberation from the Turks in 1687. The lazaretto was first built close to the entrance to the bay and the Herceg-Novi fortress, on the Topla location. The lazaretto that was built later, and somewhat further from the town, in Meljine, has been preserved in its original shape up to the present. The most recent works on the adaptation of this facility have to a major extent damaged its authenticity, and thereby also the features of a cultural asset.

Keywords: lazaretto; Venetian Republic; Boka Kotorska; Kotor; HercegNovi. 
